\title{
Colonization with multidrug-resistant bacteria increases the risk of complications and a fatal outcome after allogeneic hematopoietic cell transplantation
}

\author{
Alicja Sadowska-Klasa ${ }^{1} \cdot$ Agnieszka Piekarska $^{1}$ (D) $\cdot$ Witold Prejzner $^{1} \cdot$ Maria Bieniaszewska $^{1} \cdot$ Andrzej Hellmann $^{1}$
}

Received: 12 September 2017 / Accepted: 7 December 2017 / Published online: 19 December 2017

(C) The Author(s) 2017. This article is an open access publication

\begin{abstract}
Composition of the gut microbiota seems to influence early complications of allogeneic hematopoietic cell transplantation (HCT) such as bacterial infections and acute graft-versus-host disease (GVHD). In this study, we assessed the impact of colonization with multidrug-resistant bacteria (MDRB) prior to HCT and the use of antibiotics against anaerobic bacteria on the outcomes of HCT. We retrospectively analyzed the data of 120 patients who underwent HCT for hematologic disorders between 2012 and 2014. Fifty-one (42.5\%) patients were colonized with MDRB and 39 (32.5\%) had infections caused by MDRB. Prior colonization was significantly correlated with MDRB infections $(P<0.001)$, especially bacteremia $(P=0.038)$. A higher incidence of MDRB infections was observed in patients with acute $(P=0.014)$ or chronic $(P=0.002)$ GVHD and in patients aged $>40$ years $(P=0.002)$. Colonization had a negative impact on overall survival $(\mathrm{OS})$ after HCT (64 vs. $47 \%$ at 24 months; $P=0.034)$ and infection-associated mortality $(P<0.001)$. Use of metronidazole was correlated with an increased incidence of acute GVHD $(P<0.001)$ and lower OS $(P=0.002)$. Patients colonized with MDRB are more susceptible to life-threatening infections. Colonization with virulent flora is the most probable source of neutropenic infection; therefore, information about prior positive colonization should be crucial for the selection of empiric antibiotic therapy. The use of metronidazole, affecting the biodiversity of the intestinal microbiome, seems to have a significant impact on OS and acute GVHD.
\end{abstract}

Keywords Colonization $\cdot$ Infections $\cdot$ Transplantation $\cdot$ Metronidazole $\cdot$ Microbiome

\section{Introduction}

Allogeneic hematopoietic cell transplantation (HCT) is the curative option for various hematologic disorders. Despite progress in diagnostic and transplant-related procedures, HCT carries a risk of fatal complications related to graftversus-host disease (GVHD) and infections [1]. As a result of prolonged neutropenia and disruption of anatomic barriers as well as cellular and humoral immunodeficiency, bacterial infections are common in the early phase after HCT [2].

Alicja Sadowska-Klasa and Agnieszka Piekarska contributed equally to this work.

Agnieszka Piekarska

babajaga@gumed.edu.pl

1 Department of Hematology and Transplantology, University Clinical Center, Medical University of Gdansk, Dębinki 7, 80-952 Gdańsk, Poland
Mucosal toxicity caused by the conditioning regimens, leading to increased permeability of the gastrointestinal (GI) tract, enables colonizing bacteria to translocate to the circulation and cause bloodstream infections. Moreover, increased exposure of donor-derived lymphocytes to recipient antigens can stimulate the immune system and contribute to the development of alloreactivity [3].

The intestinal microbiome influences the maturation of the immune system and immune-mediated responses. The loss of gut microbiome diversity and generation of multidrugresistant bacteria (MDRB) are direct consequences of increased consumption of broad-spectrum antibiotics [4-6]. Treatment with antibiotics against anaerobic bacteria, such as metronidazole, can promote proinflammatory responses through the unselective destruction of gut Clostridiales. An imbalance in gut microbiome composition with dominance of MDRB may have an impact on GVHD development and lead to infectious complications. Therefore, we performed a retrospective analysis of the 120 patients to assess the 
influence of colonization with alert pathogens prior to the transplant procedure and the use of antibiotics against anaerobic bacteria on the outcomes of HCT.

\section{Patients and methods}

This study included all patients who underwent allogeneic HCT at the Department of Hematology and Transplantology, Medical University of Gdansk, Gdansk, Poland, between January 2012 and December 2014. Local Human Research Ethics Committee approved publication of the retrospective analysis since patient-identifying data were omitted to protect anonymity and the microbiological samples were collected as routine tests with prior informed consents of the patients, available in the patients' medical records.

\section{Patient characteristics}

The study included 120 patients (70 male and 50 female), with a median age of 41 years (range 1967 years), diagnosed with acute myeloid leukemia or myelodysplastic syndrome $(n=65)$, acute lymphoblastic leukemia $(n=25)$, chronic myeloproliferative neoplasms $(n=14)$, lymphomas or chronic lymphoproliferative neoplasms $(n=10)$, severe aplastic anemia, and/or paroxysmal nocturnal hemoglobinuria $(n=6)$.

Fifty-two patients received hematopoietic cells from matched unrelated donors (MUDs) or mismatched unrelated donors (MMUDs), and 68 received transplants from matched sibling donors. The source of stem cells was peripheral blood was in 111 patients $(92.5 \%)$ and bone marrow in nine patients (7.5\%). Reduced intensity/toxicity conditioning was applied in 24 patients, myeloablative conditioning was used in 92 patients and four patients received immunoablation. In all patients, cyclosporine A and short-term methotrexate were administered as GVHD prophylaxis. The patients who received allotransplants from MUDs/MMUDs additionally received rabbit anti-thymocyte globulin. The characteristics of the study group are presented in Table 1.

\section{Anti-infectious prophylaxis}

Transplantation-related procedures were performed according to institutional protocols. All patients were placed in single rooms with increased sanitary requirements (contact isolation, high-efficiency particulate air [HEPA] filters) and fed a neutropenic diet. Every patient received ciprofloxacin, acyclovir, and an anti-fungal agent as standard anti-infective prophylaxis.

\section{Colonization}

Rectal and nasal swabs and stool specimens were collected upon admission to the hospital and routinely repeated on a weekly basis during hospitalization. Colonization was defined as positive in the case of culture growth from at least one swab or a stool probe. The alert pathogens included: vancomycinresistant Enterococcus (VRE), extended-spectrum betalactamase (ESBL)-producing pathogens, and carbapenemresistant Pseudomonas aeruginosa (CRPA). Carbapenemresistant Acinetobacter baumannii and methicillin-resistant Staphylococcus aureus were not detected in the study group.

\section{Statistical analysis}

Categoric variables were expressed as absolute numbers and respective percentages, and the differences between groups were compared using Pearson's $\chi^{2}$ test. Continuous variables were expressed as median values with ranges. The relationship between continuous and categoric variables was analyzed using a nonparametric Mann-Whitney $U$ test. Survival analysis was performed according to the Kaplan-Meier method. Overall survival (OS) was calculated from the date of transplantation until death from any cause. The study population was stratified according to principal clinical and demographic characteristics, and the mean values of the groups were compared using the log-rank test. Multivariate Cox regression analysis was applied to identify independent predictive factors. A $P$ value of $<0.05$ was considered statistically significant. All analyses were performed using STATISTICA version 12 (StatSoft, Inc., Tulsa, OK, USA).

\section{Results}

\section{Colonization and infections}

Colonization with MDRB was detected in $42.5 \%$ of the patients. The most common colonizing MDRB were the following: VRE (39\%), ESBL-producing Escherichia coli (27\%), ESBL-producing Klebsiella pneumoniae (20\%), and CRPA (5\%). Multiple colonizing alert pathogens were cultured from $14 \%$ of the patients.

Despite antimicrobial prophylaxis, microbiologically documented bacterial infections occurred in $91 \%$ and fever of unknown origin was observed in $72.5 \%$ of the patients. MDRB infections were diagnosed in $32.5 \%$ of the entire study group (39 patients). Among the patients who developed MDRB infections, $50 \%$ occurred to be colonized upon admission to the transplant unit and the rest of them acquired the positive colonization status during the hospitalization. There was a significantly higher incidence of MDRB infections among the group previously colonized $(P<0.001)$, and the 
Table 1 Patient characteristics and colonization status

\begin{tabular}{|c|c|c|c|}
\hline & All patients & Noncolonized & Colonized \\
\hline \multicolumn{4}{|l|}{ Basic demographic characteristics } \\
\hline Group size, no. (\%) & $120(100)$ & $69(57.5)$ & $51(42.5)$ \\
\hline $\begin{array}{l}\text { Sex distribution: female/male, no. } \\
(\%)\end{array}$ & $50(42) / 70(58)$ & $29(42) / 40(58)$ & $21(41) / 30(59)$ \\
\hline $\begin{array}{l}\text { Age at HCT, median (range), } \\
\text { years }\end{array}$ & $41(19-67)$ & $38(19-67)$ & $44(21-66)$ \\
\hline Age $>40$ years, no. $(\%)$ & $59(49)$ & $39(56.5)$ & $20(39)$ \\
\hline \multicolumn{4}{|l|}{ Diagnosis } \\
\hline AML/MDS, no. (\%) & $65(54)$ & $39(57)$ & $26(51)$ \\
\hline ALL, no. $(\%)$ & $25(21)$ & $13(19)$ & $12(23)$ \\
\hline CML/MF/CMML, no. (\%) & $14(11.5)$ & $9(13)$ & $5(10)$ \\
\hline NHL/HL/CLL/MM, no. (\%) & $10(8.5)$ & $6(9)$ & $4(8)$ \\
\hline sAA/PNH, no. (\%) & $6(5)$ & $2(3)$ & $4(8)$ \\
\hline \multicolumn{4}{|l|}{ Transplant characteristics } \\
\hline $\begin{array}{l}\text { Donor type: MUD or } \\
\text { MMUD/MSD, no. }(\%)\end{array}$ & $68(57) / 52(43)$ & $40(58) / 29(42)$ & $28(55) / 23(45)$ \\
\hline Graft source: PB/BM, no. (\%) & $111(92.5) / 9(7.5)$ & $64(93) / 5(7)$ & $47(92) / 4(8)$ \\
\hline $\begin{array}{l}\text { Conditioning regimen: } \\
\text { MAC/RTC or RIC, no. (\%) }\end{array}$ & $92(77) / 24(20)$ & $55(80) / 12(17)$ & $37(72.5) / 12(23.5)$ \\
\hline $\begin{array}{l}\text { Conditioning regimen: } \\
\text { immunoablation, no. }(\%)\end{array}$ & $4(3)$ & $2(3)$ & $2(4)$ \\
\hline $\begin{array}{l}\text { Day of neutrophil engraftment, } \\
\text { median (range) }\end{array}$ & 23 (14-not achieved) & 23 (14-not achieved) & 23 (14-not achieved) \\
\hline $\begin{array}{l}\mathrm{ANC}>500 / \mathrm{mm}^{3} \text { before day } 20 \text {, } \\
\text { no. }(\%)\end{array}$ & $36(30)$ & $24(35)$ & $12(24)$ \\
\hline
\end{tabular}

$H C T$ hematopoietic cell transplantation, $A M L / M D S$ acute myeloid leukemia/myelodysplastic syndrome, $A L L$ acute lymphoblastic leukemia, $C M L$ chronic myeloid leukemia, $M F$ myelofibrosis, $C M M L$ chronic myelomonocytic leukemia, $N H L$ non-Hodgkin lymphoma, $H L$ Hodgkin lymphoma, $C L L$ chronic lymphocytic leukemia, $M M$ multiple myeloma, $S A A$ severe aplastic anemia, $P N H$ paroxysmal nocturnal hemoglobinuria, $M U D$ matched unrelated donor, $M M U D$ mismatched unrelated donor, $M S D$ matched sibling donor, MAC myeloablative conditioning, RTC reduced toxicity conditioning, RIC reduced intensity conditioning, $A N C$ absolute neutrophil count pathogen most commonly detected was ESBL-producing K. pneumoniae $(31 \%)$.

GI infections were diagnosed on the basis of symptomatic enterocolitis and the isolation of any bacteria potentially pathogenic to the intestines (VRE and Klebsiella isolates were excluded). There were $16(41 \%)$ urinary tract infections, 13 $(33.8 \%)$ bloodstream infections, $6(15.4 \%)$ GI infections, and $4(10.3 \%)$ respiratory tract infections. The distribution of the etiologic factors and types of infection are presented in Fig. 1. Clostridium difficile enterocolitis was added to the graphic presentation as a direct consequence of antibiotic therapy.

There was a significantly higher incidence of MDRB bacteremia in the colonized group than in the noncolonized group (16 vs. 6\%; $P=0.038$ ), and ESBLproducing $K$. pneumoniae was the most common cause of bloodstream infections $(69 \%)$. There was a significant correlation between pre-colonization with ESBL-producing $K$. pneumoniae $(P<0.001)$, ESBL-producing $E$. coli $(P=$ $0.01)$, and CRPA $(P=0.003)$ and subsequent bacteremia caused by one of these pathogens. However, we did not observe a significant correlation in the case of colonization with $\operatorname{VRE}(P=0.08)$.

\section{Engraftment, graft-versus-host disease, and infections}

The median time between the detected positive MDRB colonization and infection occurrence was 16 days (mean 26 days). Most infections developed during agranulocytosis but there was the second peak in patients treated due to GVHD. The median time to engraftment was 23 days after HCT. Early regeneration of hematopoiesis, defined as an absolute neutrophil count $\geq 500 / \mathrm{mm}^{3}$ before day 20 after HCT, was observed in 36 patients. Ten patients did not achieve engraftment. There was no significant correlation between the day of engraftment and the incidence of infections with alert pathogens $(P=$ $0.25)$. MDRB infections were more common in patients with active acute $(P=0.014)$ or chronic GVHD $(P=0.002)$, as well as in patients age $>40$ years $(P=0.002)$. 
Fig. 1 Distribution of etiological factors and types of infection. Vancomycin-resistant Enterococcus (VRE), extendedspectrum beta-lactamase (ESBL)producing Klebsiella pneumoniae (K. pneumoniae ESBL), ESBLproducing Escherichia coli (E.coli ESBL), carbapenemresistant Pseudomonas aeruginosa (CRPA)

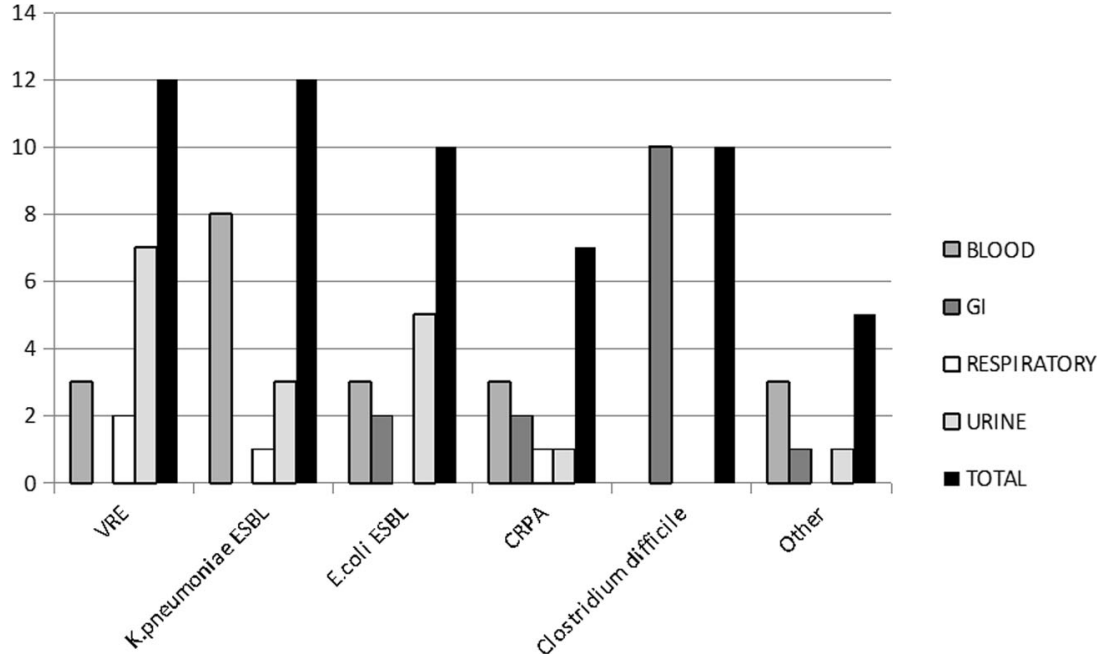

\section{Colonization and graft-versus-host disease}

Acute GVHD was diagnosed in $22 \%$ of the patients (grade I/II, 9\%; grade III/IV, 13\%), with subsequent chronic GVHD development in $14 \%$ of the patients. The incidence of acute GVHD showed a tendency to be higher in the colonized group than in the noncolonized group (27 vs. 18\%); however, the difference was not significant $(P=0.26)$. We observed a higher incidence of acute GVHD among patients colonized with more than one species of MDRB $(P=0.046)$.

\section{Metronidazole and acute graft-versus-host disease}

Of the study group, 17 patients (14\%) received metronidazole, as treatment for $C$. difficile enterocolitis in ten patients and for other indications (cholecystitis, Helicobacter pylori eradication, typhlitis) in seven patients. $C$. difficile was the cause of infections in 13 HCT recipients (Fig. 1). Metronidazole was the first therapeutic choice in 10 patients (77\%); however, only three patients responded, and the remaining seven patients required vancomycin for persistent infection. Three of the 13 patients received vancomycin as the first-line treatment and experienced complete resolution of the symptoms.

A sub-analysis of the proportion of our study group treated with broad-spectrum antibiotics against anaerobic bacteria revealed a temporal relationship between the introduction of metronidazole for $C$. difficile infection and the development or aggravation of acute GVHD $(P<0.001)$. A similar correlation was noted in the patient population treated with metronidazole for reasons other than $C$. difficile infection $(P<0.05)$.

\section{Mortality}

The median follow-up time was 17 months (range 0.447 months). The estimated OS rates for the entire study group were 73,65 , and $59 \%$ after 6,12 , and 24 months post-HCT, respectively (Fig. 2a). Forty-nine patients (41\%) died during follow-up from the following: relapse (13\%), infections (10\%), GVHD-related complications (14\%), or both GVHD and infections (3\%).

Analysis of the MDRB-colonized group showed a significantly higher mortality rate $(P=0.034)$ and infectionassociated mortality rate $(P<0.001)$ compared with the noncolonized group. The OS rates at 24 months after HCT were 47 and $64 \%$ in the colonized and noncolonized groups, respectively $(P<0.05$; Fig. $2 b)$. Multivariate analysis identified HCT from MUDs (hazard ratio [HR], 2.2; 95\% confidence interval $[\mathrm{CI}], 1.2-4 ; P=0.01)$ and metronidazole use (HR, 3; 95\% CI, 1.6-5.9; $P=0.001$ ) as factors associated with reduced OS (Fig. 2c). Age $<40$ years at transplantation was associated with a better OS (HR, 0.3; 95\% CI, 0.2-0.6; $P=$ 0.0002; Fig. 2d).

\section{Discussion}

Despite progress in diagnosis and therapy, infections and GVHD-related complications remain the most common causes of transplant-related mortality (TRM) post-HCT [1]. Eradication of the gut microbiome has been a subject of interest since the early 1970s; at the time, a germ-free environment was believed to limit infection rates and GVHD development $[7,8]$. Later, isolation procedures, HEPA filters, a neutropenic diet, and gut decontamination using antibiotics were introduced to reduce TRM [9-12]. Now, taking into account the immunoregulatory role of the healthy microbiome, the routine administration of prophylactic antibiotics in hematooncological patients and after HCT should be reconsidered [13-16].

The burden of colonizing bacterial flora was recently estimated to be about $0.2 \mathrm{~kg}$, and the number of bacterial cells in the human body was determined to be comparable to that of 

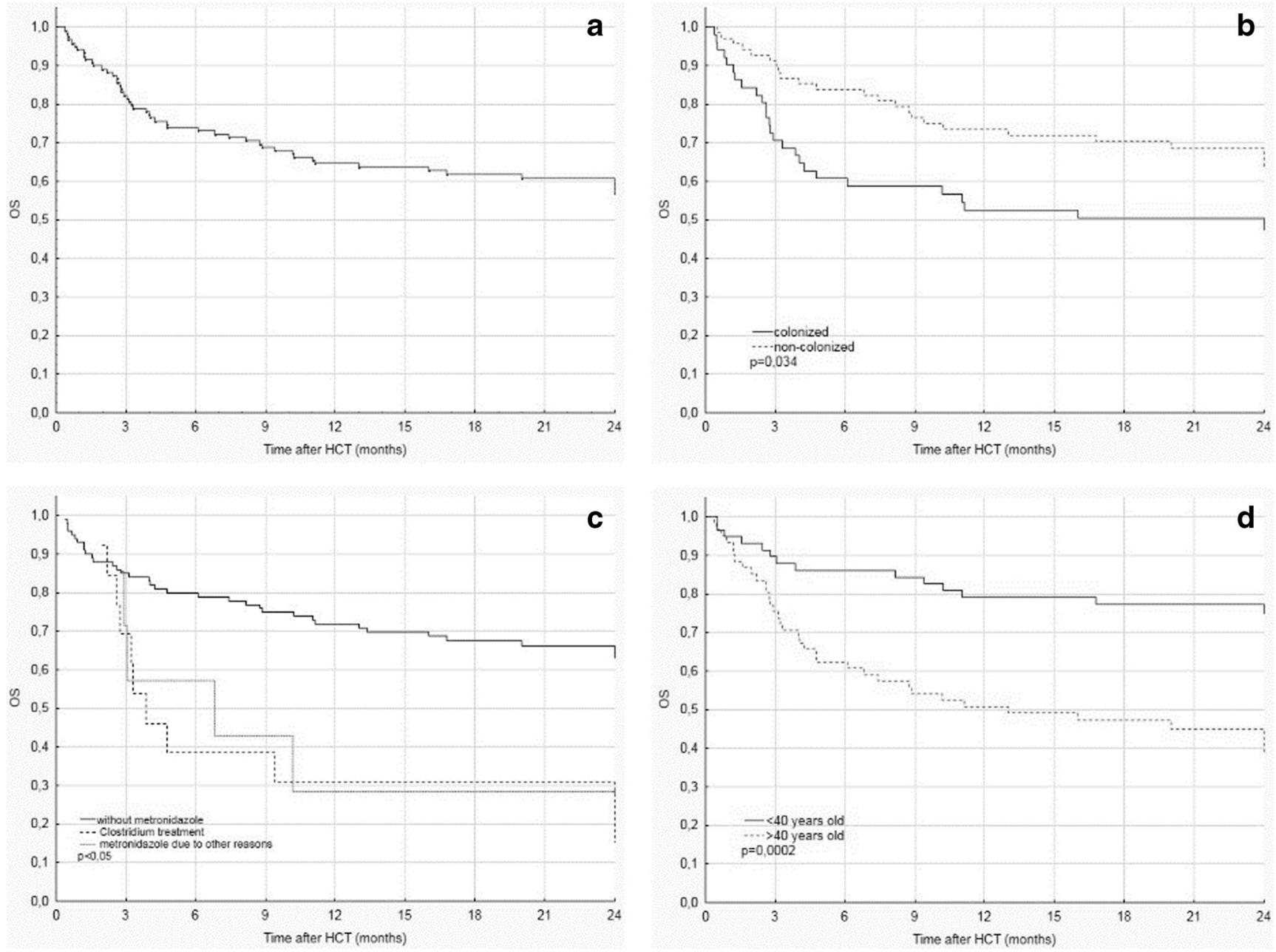

Fig. 2 Factors influencing overall survival after hematopoietic cell transplantation. a Overall survival (OS) in the entire study group; b effect of colonization with multidrug-resistant bacteria (solid line) versus no prior colonization (dashed line); $\mathbf{c}$ OS after metronidazole use

for Clostridium difficile infection (dashed line) and other indications (dotted line) versus OS in patients unexposed to metronidazole (solid line); $\mathbf{d}$ OS stratified by age $<40$ (solid line) versus $>40$ (dashed line) years. Overall survival (OS), hematopoietic cell transplantation (HCT)

host cells [17]. The composition of the gut microbiome can be precisely assessed, and $>1000$ species have already been identified by 16 ribosomal RNA gene sequencing [18]. Besides the degradation of digestion products and production of vitamins, the intestinal microbiome plays a pivotal role in immune system regulation. It maintains the balance between the pro- and anti-inflammatory effectors, including immunotolerant regulatory $\mathrm{T}$ lymphocytes (Tregs) and proinflammatory Th17 lymphocytes [19-26]. Th17 lymphocytes protect the intestinal mucous membrane from pathogens but, in certain circumstances, can catalyze an inflammatory process that leads to GVHD development [27]. In the presence of short-chain fatty acids produced by Clostridiales, naïve $\mathrm{T}$ lymphocytes are induced for the generation of extrathymic Tregs $[24,28,29]$, whereas proinflammatory cytokines or segmented filamentous bacteria direct them to generate Th17 cells [30]. Intestinal epithelial cells (IECs) create a physiologic and biochemical barrier between the commensal

microorganisms of the gut and host tissues [21]. High-dose chemo- and radiotherapy prior to HCT impairs GI epithelial integrity, which may aid the translocation of colonizing bacteria into the circulation, resulting in severe infectious complications. Additionally, increased exposure to antigens of the host histocompatibility complex related to IECs damage promotes acute GVHD development [3, 31].

In the study group, $42.5 \%$ of the patients were colonized with MDRB and $14 \%$ were carriers of more than one alert pathogen. The high percentage of colonized patients is unsurprising: many of the patients requiring HCT had a history of aggressive treatment of the underlying disease, requiring prolonged hospitalization and administration of broadspectrum antibiotics for life-threatening infections. Colonization with MDRB had a significant impact on nonrelapse mortality, leading to a lower OS 2 years after HCT and higher mortality due to infections than those of noncolonized patients. The higher mortality rate in the colonized group may 
have been caused by the loss of microbiome diversity and consequent expansion of pathogenic bacteria within the niches of gut bacteria [32-34]. Bloodstream infections with MDRB were more common in patients colonized with ESBL-producing $K$. pneumoniae, ESBL-producing E. coli, and CRPA. There was no significant correlation between colonization with VRE and bacteremia caused by this pathogen. Similar results have been presented by other authors $[35,36]$. During episodes of neutropenic fever, the etiological factor is not always identified. Because the colonizing virulent flora is the most probable source of a neutropenic infection, information about prior positive colonization is important for the selection of empiric antibiotic therapy to reduce the risk of a fatal outcome.

As mentioned earlier, the fragile balance between pro- and anti-inflammatory mechanisms can be disrupted by changes in microbiome composition, resulting from conditioning chemotherapy and the use of antibiotics. In murine models, disturbances in the commensal gut flora, with domination of Enterobacteriales (E. coli, Klebsiella, and Enterobacter), Lactobacillales (Lactobacillus, Enterococcus, and Streptococcus), and a reduction in Firmicutes species (including Clostridiales), were correlated with acute GVHD development [37]. A similar shift towards enterococci, particularly observed after antibiotic prophylaxis and confirmed by the metagenomic analysis of the stool microbiome, preceded the intestinal manifestation of acute GVHD in a human population [38]. This phenomenon can be explained by the ability of enterococci to create a biofilm and produce epitheliolysins and other toxins that disrupt the integrity of the epithelial barrier, intensifying inflammatory and immune responses and leading to increased production of proinflammatory substances, such as tumor necrosis factor $[39,40]$. Although we did not find a significant correlation between colonization with VRE and the occurrence of acute GVHD or VRE bacteremia, acute GVHD was more common in the group colonized with multiple alert pathogens, including VRE.

Enterococci have the ability to grow excessively in favorable conditions, pushing the commensal flora out of their niches. Although prophylactic use of ciprofloxacin lowers the rate of Gram-negative bacteremia, it does not prevent streptococcal or enterococcal septic episodes and, by causing an imbalance in anaerobic commensals, may increase the risk of colonization with MDRB, such as VRE [41]. This observation is confirmed by the profile of colonizing bacteria in the proportion of our study group receiving ciprofloxacin prophylaxis; despite prophylaxis, $>90 \%$ of the patients developed infectious complications during the neutropenic period after HCT. In contrast to fluoroquinolones, rifaximin represents a perfect prophylactic agent that provides protection against bacteremia and preserves the physiologic balance of the gut microbiome [42, 43].

Of the intestinal microbiota, $90 \%$ consists of anaerobic bacteria [44]. Administration of broad-spectrum agents selectively targeting anaerobic bacterial flora may lead to excessive proliferation of aerobic and relatively anaerobic pathogens. Among the HCT recipients examined, patients treated with metronidazole exhibited a significantly lower OS. Moreover, the incidence of acute GVHD with more severe manifestation (grade III/IV) was higher in the metronidazole-treated group. This observation may be partially related to the unselective depletion of all Clostridiales, alongside the desired elimination of $C$. difficile. Therapy with metronidazole failed in most patients with $C$. difficile infections. Based on our data and the guidelines of the European Society of Clinical Microbiology and Infectious Diseases, patients with $C$. difficile infections after HCT should be treated as a high-risk group for severe complications. Therefore, more potent oral vancomycin or novel therapies (e.g., fidaxomicin) should be administered instead of metronidazole as the firstline therapy [45]. The impact of the microbiome on many conditions, including autoimmune disorders [19, 20, 46, 47], cancer [48], and chemo-resistance [49], indicate the necessity of new strategies that maintain the physiologic composition of the gut microbiota. Fecal microbiome transplantation (FMT) has been investigated as a method to restore the composition of the gut microflora, and may eradicate MDRB before HCT, leading to reduction in acute GVHD and TRM. The first data concerning the successful use of FMT for steroid-resistant gut acute GVHD, C. difficile infection, or decolonization of resistant pathogens have been already published [50,51].

Homeostasis of the human microbiome is important and requires further investigation. The data already available, confirmed by the findings of our study, have practical implications for the selection of prophylactic and infection-driven antibiotic strategies that may improve the outcomes of immunocompromised patients after HCT.

Author contributions A.S.-K.: concept/design; data collection; statistics; data analysis and interpretation; drafting article; critical revision

A.P.: concept/design; data collection; data analysis and interpretation; drafting article; final version of the manuscript

W.P., M.B., A.H.: data interpretation; critical revision. All authors approved the final version of the manuscript.

Compliance with ethical standards The procedures and retrospective data analysis were approved by the local ethics committee and were conducted in accordance with the current version of the Declaration of Helsinki.

Conflict of interest The authors declare that they have no conflict of interest.

Open Access This article is distributed under the terms of the Creative Commons Attribution 4.0 International License (http:// creativecommons.org/licenses/by/4.0/), which permits unrestricted use, distribution, and reproduction in any medium, provided you give appropriate credit to the original author(s) and the source, provide a link to the Creative Commons license, and indicate if changes were made. 


\section{References}

1. Gratwohl A, Brand R, Frassoni F, Rocha V, Niederwieser D, Reusser P, Einsele H, Cordonnier C, Acute, Chronic Leukemia Working P, Infectious Diseases Working Party of the European Group for B, Marrow T (2005) Cause of death after allogeneic haematopoietic stem cell transplantation (HSCT) in early leukaemias: an EBMT analysis of lethal infectious complications and changes over calendar time. Bone Marrow Transplant 36(9):757769. https://doi.org/10.1038/sj.bmt.1705140

2. Cuthbert RJ, Iqbal A, Gates A, Toghill PJ, Russell NH (1995) Functional hyposplenism following allogeneic bone marrow transplantation. J Clin Pathol 48(3):257-259. https://doi.org/10.1136/ jep.48.3.257

3. Johansson JE, Ekman T (2007) Gut toxicity during hemopoietic stem cell transplantation may predict acute graft-versus-host disease severity in patients. Dig Dis Sci 52(9):2340-2345. https://doi.org/ 10.1007/s10620-006-9404-x

4. Bell BG, Schellevis F, Stobberingh E, Goossens H, Pringle M (2014) A systematic review and meta-analysis of the effects of antibiotic consumption on antibiotic resistance. BMC Infect Dis 14(1):13. https://doi.org/10.1186/1471-2334-14-13

5. Roca I, Akova M, Baquero F, Carlet J, Cavaleri M, Coenen S, Cohen J, Findlay D, Gyssens I, Heure OE, Kahlmeter G, Kruse H, Laxminarayan R, Liebana E, Lopez-Cerero L, MacGowan A, Martins M, Rodriguez-Bano J, Rolain JM, Segovia C, Sigauque B, Taconelli E, Wellington E, Vila J (2015) The global threat of antimicrobial resistance: science for intervention. New Microbes New Infect 6:22-29. https://doi.org/10.1016/j.nmni.2015.02.007

6. Denis B, Lafaurie M, Donay JL, Fontaine JP, Oksenhendler E, Raffoux E, Hennequin C, Allez M, Socie G, Maziers N, Porcher R, Molina JM (2015) Prevalence, risk factors, and impact on clinical outcome of extended-spectrum beta-lactamase-producing Escherichia coli bacteraemia: a five-year study. Int J Infect Dis 39:1-6. https://doi.org/10.1016/j.ijid.2015.07.010

7. van Bekkum DW, Roodenburg J, Heidt PJ, van der Waaij D (1974) Mitigation of secondary disease of allogeneic mouse radiation chimeras by modification of the intestinal microflora. J Natl Cancer Inst 52(2):401-404. https://doi.org/10.1093/jnci/52.2.401

8. Jones JM, Wilson R, Bealmear PM (1971) Mortality and gross pathology of secondary disease in germfree mouse radiation chimeras. Radiat Res 45(3):577-588. https://doi.org/10.2307/3573066

9. Petersen FB, Buckner CD, Clift RA, Nelson N, Counts GW, Meyers JD, Thomas ED (1987) Infectious complications in patients undergoing marrow transplantation: a prospective randomized study of the additional effect of decontamination and laminar air flow isolation among patients receiving prophylactic systemic antibiotics. Scand J Infect Dis 19(5):559-567. https://doi.org/10. 3109/00365548709032423

10. Passweg JR, Rowlings PA, Atkinson KA, Barrett AJ, Gale RP, Gratwohl A, Jacobsen N, Klein JP, Ljungman P, Russell JA, Schaefer UW, Sobocinski KA, Vossen JM, Zhang MJ, Horowitz MM (1998) Influence of protective isolation on outcome of allogeneic bone marrow transplantation for leukemia. Bone Marrow Transplant 21(12):1231-1238. https://doi.org/10.1038/sj.bmt. 1701238

11. Beelen DW, Elmaagacli A, Muller KD, Hirche H, Schaefer UW (1999) Influence of intestinal bacterial decontamination using metronidazole and ciprofloxacin or ciprofloxacin alone on the development of acute graft-versus-host disease after marrow transplantation in patients with hematologic malignancies: final results and longterm follow-up of an open-label prospective randomized trial. Blood 93(10):3267-3275

12. Vossen JM, Heidt PJ, van den Berg H, Gerritsen EJ, Hermans J, Dooren LJ (1990) Prevention of infection and graft-versus-host disease by suppression of intestinal microflora in children treated with allogeneic bone marrow transplantation. Eur J Clin Microbiol Infect Dis 9(1):14-23. https://doi.org/10.1007/BF01969527

13. Mercadante AC, Perobelli SM, Alves AP, Goncalves-Silva T, Mello W, Gomes-Santos AC, Miyoshi A, Azevedo V, Faria AM, Bonomo A (2014) Oral combined therapy with probiotics and alloantigen induces B cell-dependent long-lasting specific tolerance. J Immunol 192(4):1928-1937. https://doi.org/10.4049/jimmunol.1301034

14. Gerbitz A, Schultz M, Wilke A, Linde HJ, Scholmerich J, Andreesen R, Holler E (2004) Probiotic effects on experimental graft-versus-host disease: let them eat yogurt. Blood 103(11): 4365-4367. https://doi.org/10.1182/blood-2003-11-3769

15. Trifilio S, Helenowski I, Giel M, Gobel B, Pi J, Greenberg D, Mehta J (2012) Questioning the role of a neutropenic diet following hematopoetic stem cell transplantation. Biol Blood Marrow Transplant 18(9):1385-1390. https://doi.org/10.1016/j.bbmt.2012. 02.015

16. Russell JA, Chaudhry A, Booth K, Brown C, Woodman RC, Valentine K, Stewart D, Ruether JD, Ruether BA, Jones AR, Coppes MJ, Bowen T, Anderson R, Bouchard M, Rallison L, Stotts M, Poon MC (2000) Early outcomes after allogeneic stem cell transplantation for leukemia and myelodysplasia without protective isolation: a 10-year experience. Biol Blood Marrow Transplant 6(2):109-114. https://doi.org/10.1016/S1083-8791(00) 70073-5

17. Sender R, Fuchs S, Milo R (2016) Are we really vastly outnumbered? Revisiting the ratio of bacterial to host cells in humans. Cell 164(3):337-340. https://doi.org/10.1016/j.cell.2016. 01.013

18. Murphy S, Nguyen VH (2011) Role of gut microbiota in graftversus-host disease. Leuk Lymphoma 52(10):1844-1856. https:// doi.org/10.3109/10428194.2011.580476

19. HJ W, Wu E (2012) The role of gut microbiota in immune homeostasis and autoimmunity. Gut Microbes 3(1):4-14. https://doi.org/ 10.4161/gmic. 19320

20. Belkaid Y, Hand TW (2014) Role of the microbiota in immunity and inflammation. Cell 157(1):121-141. https://doi.org/10.1016/j. cell.2014.03.011

21. Peterson LW, Artis D (2014) Intestinal epithelial cells: regulators of barrier function and immune homeostasis. Nat Rev Immunol 14(3): 141-153. https://doi.org/10.1038/nri3608

22. Coombes JL, Siddiqui KR, Arancibia-Carcamo CV, Hall J, Sun CM, Belkaid Y, Powrie F (2007) A functionally specialized population of mucosal CD103+ DCs induces Foxp3+ regulatory T cells via a TGF-beta and retinoic acid-dependent mechanism. J Exp Med 204(8):1757-1764. https://doi.org/10.1084/jem.20070590

23. Round JL, Mazmanian SK (2010) Inducible Foxp 3+ regulatory Tcell development by a commensal bacterium of the intestinal microbiota. Proc Natl Acad Sci U S A 107(27):12204-12209. https:// doi.org/10.1073/pnas.0909122107

24. Atarashi K, Tanoue T, Shima T, Imaoka A, Kuwahara T, Momose Y, Cheng G, Yamasaki S, Saito T, Ohba Y, Taniguchi T, Takeda K, Hori S, Ivanov II, Umesaki Y, Itoh K, Honda K (2011) Induction of colonic regulatory $\mathrm{T}$ cells by indigenous clostridium species. Science 331(6015):337-341. https://doi.org/10.1126/science. 1198469

25. Jenq RR, Taur Y, Devlin SM, Ponce DM, Goldberg JD, Ahr KF, Littmann ER, Ling L, Gobourne AC, Miller LC, Docampo MD, Peled JU, Arpaia N, Cross JR, Peets TK, Lumish MA, Shono Y, Dudakov JA, Poeck H, Hanash AM, Barker JN, Perales MA, Giralt SA, Pamer EG, van den Brink MR (2015) Intestinal Blautia is associated with reduced death from graft-versus-host disease. Biol Blood Marrow Transplant 21(8):1373-1383. https://doi.org/10. 1016/j.bbmt.2015.04.016

26. Shono Y, Docampo MD, Peled JU, Perobelli SM, Jenq RR (2015) Intestinal microbiota-related effects on graft-versus-host disease. Int 
J Hematol 101(5):428-437. https://doi.org/10.1007/s12185-0151781-5

27. Omenetti S, Pizarro TT (2015) The Treg/Th17 Axis: a dynamic balance regulated by the gut microbiome. Front Immunol 6:639. https://doi.org/10.3389/fimmu.2015.00639

28. Arpaia N, Campbell C, Fan X, Dikiy S, van der Veeken J, deRoos P, Liu H, Cross JR, Pfeffer K, Coffer PJ, Rudensky AY (2013) Metabolites produced by commensal bacteria promote peripheral regulatory T-cell generation. Nature 504(7480):451-455. https:// doi.org/10.1038/nature12726

29. Atarashi K, Tanoue T, Oshima K, Suda W, Nagano Y, Nishikawa H, Fukuda S, Saito T, Narushima S, Hase K, Kim S, Fritz JV, Wilmes P, Ueha S, Matsushima K, Ohno H, Olle B, Sakaguchi S, Taniguchi T, Morita H, Hattori M, Honda K (2013) Treg induction by a rationally selected mixture of Clostridia strains from the human microbiota. Nature 500(7461):232-236. https://doi.org/10.1038/ nature12331

30. Ivanov II, Atarashi K, Manel N, Brodie EL, Shima T, Karaoz U, Wei D, Goldfarb KC, Santee CA, Lynch SV, Tanoue T, Imaoka A, Itoh K, Takeda K, Umesaki Y, Honda K, Littman DR (2009) Induction of intestinal Th17 cells by segmented filamentous bacteria. Cell 139(3):485-498. https://doi.org/10.1016/j.cell.2009.09. 033

31. Ferrara JL, Levine JE, Reddy P, Holler E (2009) Graft-versus-host disease. Lancet 373(9674):1550-1561. https://doi.org/10.1016/ S0140-6736(09)60237-3

32. Taur Y, Jenq RR, Perales MA, Littmann ER, Morjaria S, Ling L, No D, Gobourne A, Viale A, Dahi PB, Ponce DM, Barker JN, Giralt S, van den Brink M, Pamer EG (2014) The effects of intestinal tract bacterial diversity on mortality following allogeneic hematopoietic stem cell transplantation. Blood 124(7):1174-1182. https://doi.org/ 10.1182/blood-2014-02-554725

33. Taur Y, Xavier JB, Lipuma L, Ubeda C, Goldberg J, Gobourne A, Lee YJ, Dubin KA, Socci ND, Viale A, Perales MA, Jenq RR, van den Brink MR, Pamer EG (2012) Intestinal domination and the risk of bacteremia in patients undergoing allogeneic hematopoietic stem cell transplantation. Clin Infect Dis 55(7):905-914. https://doi.org/ $10.1093 / \mathrm{cid} / \mathrm{cis} 580$

34. Ubeda C, Taur Y, Jenq RR, Equinda MJ, Son T, Samstein M, Viale A, Socci ND, van den Brink MR, Kamboj M, Pamer EG (2010) Vancomycin-resistant Enterococcus domination of intestinal microbiota is enabled by antibiotic treatment in mice and precedes bloodstream invasion in humans. J Clin Invest 120(12):4332-4341. https://doi.org/10.1172/JCI43918

35. Bilinski J, Robak K, Peric Z, Marchel H, Karakulska-Prystupiuk E, Halaburda K, Rusicka P, Swoboda-Kopec E, Wroblewska M, Wiktor-Jedrzejczak W, Basak GW (2016) Impact of gut colonization by antibiotic-resistant bacteria on the outcomes of allogeneic hematopoietic stem cell transplantation: a retrospective, singlecenter study. Biol Blood Marrow Transplant 22(6):1087-1093. https://doi.org/10.1016/j.bbmt.2016.02.009

36. Liss BJ, Vehreschild JJ, Cornely OA, Hallek M, Fatkenheuer G, Wisplinghoff H, Seifert H, Vehreschild MJ (2012) Intestinal colonisation and blood stream infections due to vancomycin-resistant enterococci (VRE) and extended-spectrum beta-lactamaseproducing Enterobacteriaceae (ESBLE) in patients with haematological and oncological malignancies. Infection 40(6):613-619. https://doi.org/10.1007/s15010-012-0269-y

37. Jenq RR, Ubeda C, Taur Y, Menezes CC, Khanin R, Dudakov JA, Liu C, West ML, Singer NV, Equinda MJ, Gobourne A, Lipuma L, Young LF, Smith OM, Ghosh A, Hanash AM, Goldberg JD, Aoyama K, Blazar BR, Pamer EG, van den Brink MR (2012) Regulation of intestinal inflammation by microbiota following allogeneic bone marrow transplantation. J Exp Med 209(5):903-911. https://doi.org/10.1084/jem.20112408
38. Holler E, Butzhammer P, Schmid K, Hundsrucker C, Koestler J, Peter K, Zhu W, Sporrer D, Hehlgans T, Kreutz M, Holler B, Wolff D, Edinger M, Andreesen R, Levine JE, Ferrara JL, Gessner A, Spang R, Oefner PJ (2014) Metagenomic analysis of the stool microbiome in patients receiving allogeneic stem cell transplantation: loss of diversity is associated with use of systemic antibiotics and more pronounced in gastrointestinal graft-versus-host disease. Biol Blood Marrow Transplant 20(5):640-645. https://doi.org/10. 1016/j.bbmt.2014.01.030

39. Steck N, Hoffmann M, Sava IG, Kim SC, Hahne H, Tonkonogy SL, Mair K, Krueger D, Pruteanu M, Shanahan F, Vogelmann R, Schemann M, Kuster B, Sartor RB, Haller D (2011) Enterococcus faecalis metalloprotease compromises epithelial barrier and contributes to intestinal inflammation. Gastroenterology 141(3):959-971. https://doi.org/10.1053/j. gastro.2011.05.035

40. Sava IG, Heikens E, Huebner J (2010) Pathogenesis and immunity in enterococcal infections. Clin Microbiol Infect 16(6):533-540. https://doi.org/10.1111/j.1469-0691.2010.03213.x

41. Taur Y, Pamer EG (2013) The intestinal microbiota and susceptibility to infection in immunocompromised patients. Curr Opin Infect Dis 26(4):332-337. https://doi.org/10.1097/QCO. 0b013e3283630dd 3

42. Weber D, Oefner PJ, Dettmer K, Hiergeist A, Koestler J, Gessner A, Weber M, Stammler F, Hahn J, Wolff D, Herr W, Holler E (2016) Rifaximin preserves intestinal microbiota balance in patients undergoing allogeneic stem cell transplantation. Bone Marrow Transplant 51(8):1087-1092. https://doi.org/10.1038/bmt.2016.66

43. Weber D, Oefner PJ, Hiergeist A, Koestler J, Gessner A, Weber M, Hahn J, Wolff D, Stammler F, Spang R, Herr W, Dettmer K, Holler E (2015) Low urinary indoxyl sulfate levels early after transplantation reflect a disrupted microbiome and are associated with poor outcome. Blood 126(14):1723-1728. https://doi.org/10.1182/ blood-2015-04-638858

44. Guarner F, Malagelada JR (2003) Gut flora in health and disease. Lancet 361(9356):512-519. https://doi.org/10.1016/S01406736(03)12489-0

45. Debast SB, Bauer MP, Kuijper EJ, European Society of Clinical M, Infectious D (2014) European Society of Clinical Microbiology and Infectious Diseases: update of the treatment guidance document for Clostridium difficile infection. Clin Microbiol Infect 20(Suppl 2): 1-26. https://doi.org/10.1111/1469-0691.12418

46. Scott KP, Antoine JM, Midtvedt T, van Hemert S (2015) Manipulating the gut microbiota to maintain health and treat disease. Microb Ecol Health Dis 26(0):25877. https://doi.org/10.3402/ mehd.v26.25877

47. Marchesi JR, Adams DH, Fava F, Hermes GD, Hirschfield GM, Hold G, Quraishi MN, Kinross J, Smidt H, Tuohy KM, Thomas LV, Zoetendal EG, Hart A (2016) The gut microbiota and host health: a new clinical frontier. Gut 65(2):330-339. https://doi.org/10.1136/ gutjnl-2015-309990

48. Iida N, Dzutsev A, Stewart CA, Smith L, Bouladoux N, Weingarten RA, Molina DA, Salcedo R, Back T, Cramer S, Dai RM, Kiu H, Cardone M, Naik S, Patri AK, Wang E, Marincola FM, Frank KM, Belkaid Y, Trinchieri G, Goldszmid RS (2013) Commensal bacteria control cancer response to therapy by modulating the tumor microenvironment. Science 342(6161):967-970. https://doi.org/10.1126/ science. 1240527

49. Viaud S, Saccheri F, Mignot G, Yamazaki T, Daillere R, Hannani D, Enot DP, Pfirschke C, Engblom C, Pittet MJ, Schlitzer A, Ginhoux F, Apetoh L, Chachaty E, Woerther PL, Eberl G, Berard M, Ecobichon C, Clermont D, Bizet C, Gaboriau-Routhiau V, Cerf-Bensussan N, Opolon P, Yessaad N, Vivier E, Ryffel B, Elson CO, Dore J, Kroemer G, Lepage P, Boneca IG, Ghiringhelli F, Zitvogel 
L (2013) The intestinal microbiota modulates the anticancer immune effects of cyclophosphamide. Science 342(6161): 971-976. https://doi.org/10.1126/science.1240537

50. Kakihana K, Fujioka Y, Suda W, Najima Y, Kuwata G, Sasajima S, Mimura I, Morita H, Sugiyama D, Nishikawa $\mathrm{H}$, Hattori $\mathrm{M}$, Hino $\mathrm{Y}$, Ikegawa $\mathrm{S}$, Yamamoto $\mathrm{K}$, Toya $\mathrm{T}$, Doki N, Koizumi K, Honda K, Ohashi K (2016) Fecal microbiota transplantation for patients with steroid-resistant/ dependent acute graft-versus-host disease of the gut. Blood 128(16):2083-2088. https://doi.org/10.1182/blood-2016-05717652

51. Manges AR, Steiner TS, Wright AJ (2016) Fecal microbiota transplantation for the intestinal decolonization of extensively antimicrobial-resistant opportunistic pathogens: a review. Infect Dis (Lond) 48(8):587-592. https://doi.org/10.1080/23744235. 2016.1177199 